\title{
Pour une typologie du héros dans la poésie épique slave du Sud
}

Towards a Typology of Heroes in South Slavic Epic Song

\section{Boško Bojović}

\section{(2) OpenEdition}

Journals

Édition électronique

URL : http://journals.openedition.org/etudesbalkaniques/418

ISSN : 2102-5525

\section{Éditeur}

Association Pierre Belon

\section{Édition imprimée}

Date de publication : 1 janvier 2000

Pagination : 71-87

ISBN : 2-910860-10-8

ISSN : $1260-2116$

Référence électronique

Boško Bojović, "Pour une typologie du héros dans la poésie épique slave du Sud », Études balkaniques [En ligne], 7 | 2000, mis en ligne le 08 avril 2009, consulté le 25 avril 2019. URL : http:// journals.openedition.org/etudesbalkaniques/418

Ce document a été généré automatiquement le 25 avril 2019

Tous droits réservés 


\section{Pour une typologie du héros dans la poésie épique slave du Sud}

Towards a Typology of Heroes in South Slavic Epic Song

\section{Boško Bojović}

\section{RÉSUMÉS}

Après une introduction méthodologique sur le corpus en présence, l'auteur propose une classification historico-typologique reprenant la périodisation traditionnelle de l'épopée sudslave (poésie archaïque puis classique, chants ouskoks et haïdouks, chants des guerres d'indépendance) en attachant à chaque stade de développement une éthique spécifique du héros. Il accompagne ce travail d'éléments historiques sur les personnages littéraires qu'il analyse.

After an introduction in methodology on the known corpus, the author gives an historictypological classification based on traditional periodization of South Slav epic: archaic, then classical poetry, Uskok and Haiduk songs, independence wars songs. In relation to each stage of epic development, he describes a specific ethics of remarkable heroes, on whom he tries to give historical details.

\section{AUTEUR}

\section{BOŠKO BOJOVIĆ}

E.H.E.S.S., Paris - Centre Pierre Belon 